\title{
Impact Of Corporate Governance On Firm's Financial Performance (A Comparative Study Of Developed And Non Developed Markets)
}

\author{
Muhammad Ali
}

muhammadali06@gmail.com

\begin{abstract}
The study has been conducted to compare the impact of corporate governance on firm's financial performance between USA (Developed Country) and Pakistan (Developing Country). The corporate governance is measured by Board's Ownership, Effectiveness, Size and Structure, Its Independency, CEO Duality and Board's education and Experience whereas the firm's financial performance is measure by the Return on Asset and Return on Equity. A sample of 100 listed companies from Karachi Stock Exchange of Pakistan and New York Stock Exchange of USA has been investigated to analyze the relationship during the period 01 Jan 2010 to 31 Dec 2015 regarding their comparative firm's financial performance in respect of Corporate Governance. The impact of corporate governance in the 100 listed firms that are taken in the sample from Pakistan and USA were analyzed through collection primary data by floating the questionnaire physically in Pakistan and online for USA. The internal and external performance of firm's for both countries was measured by taking Return on Asset (ROA) and Return on Equity (ROE) as internal performance measure and Market to Book Value Ratio, of Tobin's $Q$ and Marris, for measuring the external performance. From the study it has been found that corporate governance codes are being followed in both countries but it is better in the developed countries. In Pakistan, due to most family owned business there exists some conflicts exists between the corporate governance codes drawn by SECP with their already drawn already set procedure whereas in USA strict Corporate Governance codes are being followed. The variables like Board ownership, Board Education \& Experience, effectiveness and CEO Duality has positive relationship with the firm's performance but Board Size has negative correlation. The study also found that there is no relationship between independency of director with firm's performance.
\end{abstract}

Keywords: Corporate Governance, Performance, Tobin's Q, ROA, ROE.

Suggested Citation: Suresh Muhammad Ali (2018) Impact Of Corporate Governance On Firm's Financial Performance (A Comparative Study Of Developed And Non Developed Markets), Journal of Business Management and Economic Research, Vol.2, Issue.1, pp.15-30 


\section{Introduction}

After the major scandals of organization giants like Enron and WorldCom, the attention towards the corporate governance started to emerge. Concept was corporate governance was there but it was not implemented to its core due which these types of scandal emerged. After such scandal, need for corporate governance arises as the shareholder and management are separate and similarly their interest, so a moderator was required in order to fulfil this gap and becomes a bridge between these two. Hence the board of governance was the ultimate solution for this which not only protects the share of interest of shareholders but also control the management of the organization.

In early $17^{\text {th }}$ century, the concept of corporate governance doesn't exist. This is because in those days, ownership was divided into small number of people (partnership) who also participate in the operations of the organization. So they can easily control and safeguard their interest.

The concept of corporate governance was first highlighted in academics by Richard Eells in 1960 in his paper "the structure and functioning of corporate polity" where he reveals how agency cost effect the firm's financial resources and how can this be minimized.

Broadly speaking, CG is a relationship between the company's board, management, shareholders and other stakeholders. Talking more specifically and narrow down its concept, a definition given by Shleifer and Vishny (1997), corporate governance deals with the ways in which suppliers of finance to corporations assure themselves of getting a return on their investment.

From the above definition, it is clear that the prime objective of CG is to protect the interest of shareholders and stakeholders of the company.

In the developed markets, the concept of corporate governance is proven by the studies conducted by the regulators against which they have reported that influenced the importance of corporate governance. These reports are issued by Cadbury Committee (1992), Greenbuy Committee (1995), Hampel Committee (1998) and Turnbull Committee (2003). These reports are benchmark for the rest of the world and they follow these reports. These reports have become basis for codes for CG for the rest of the world.

From the above explanation, the importance of corporate governance is now highlighted. When the interest of stakeholders is safeguarded, this will also bring positive change in performance of the organization.

Many empirical study have been conducted which shows the existence of a relationship between corporate governance and firm's financial performance. Talking about developing and developed market, the definition of corporate 
governance is different for different countries. Similarly the effect of corporate governance on firm's financial performance also varies from countries to countries. However, corporate governance is more important for emerging markets and less developed market as in developed countries, CG is being followed strictly.

Many empirical studies have been conducted to investigate a relationship between corporate governance and a firm's financial performance in the world. However, similar studies in the context of Pakistan are very rare. The concept of corporate governance in the developed world is not new and it is better implemented and followed there as compared to the developing countries like Pakistan. There are some studies made on CG being a comparative study. Major contribution in this regard given by Dr. ZA Shah (2009), he conducted a research on a comparative study between Pakistan (Developing Country) and US (Developed Country). He investigated corporate governance with the context of Ownership structure, board size and its independence, audit committee independence and CEO Duality. He found a positive relationship between the ownership structure and capital structure. This means more the involvement of the board in the management, more the debt size in the capital structure. The management will be tending to more take more risk in order to gain more return. His study was done during the period 2002 to 2007.

Z.A Shah (2009), S.A Butt (2010), Duc Vo \& Thuy Phan (2013) indicated that corporate governance can be measured through these elements: (1) Board's Ownership (2) Board Structure (3) Board Size (4) Independence of Board (5) Independence of Audit Committee and (6) CEO Duality.

In addition, a firm's financial performance is measured by the return on asset, known as the ROA ratio and return on Equity (ROE) for measuring the performance of the companies.

\section{Objective}

The objective of the study is to investigate how the performance of the firm is effected by the Corporate Governance and what is the relationship that exists between the firm's performance with the Board's Structure, Size, Effectiveness, Education, Experience and Dual position of CEO as CEO of the company as well as the Chairman of the board. The study is the extension to the work of ZA Shah (2009) as it was limited to period 2005 to 2009 for 100 listed companies of Karachi Stock Exchange in Pakistan and 1170 listed companies of New York Stock Exchange in USA. In the current study, the period has been extended from 2010 to 2015 in order to investigate the results of ZA Shah (2009) as it remains same or not as described in the hypothesis. 


\section{Significance of the study:}

The outcomes of the study will be useful in improving the understanding of investors regarding the importance of corporate governance keeping the aspect of Developed and Non Developed economies. The study contributes in the existing literature for the readers and researchers. The study has been made comprehensive by incorporating different aspect of business both from Developing and Non Developing Countries.

\section{Plan / Organization of the Study:}

Section 1 provides the objectives of study and introduces the research purpose and why Corporate Governance is important in firms. Section 2 contains the literature review; section 3 explains the research methodology used in the analysis; section 4 consists of analysis of data and empirical results. Section 5 endorses the findings and discussion; study is concluded in section 6 and section 7 provides the recommendations upon the findings and implication for the investors.

\section{Hypothesis:}

Hypothesis relating to each variable relating to the study is given as under:

\subsection{Board's Ownership:}

$\mathrm{H}_{1}: \quad$ There is a positive relationship between the Board's ownership and Firm's Financial Performance.

$\mathrm{H}_{2}$ : There is a negative relationship between the Board's ownership and Firm's Financial Performance.

\subsection{Board's Effectiveness:}

$\mathrm{H}_{1}: \quad$ There is a positive relationship between the Board's effectiveness and Firm's Financial Performance.

$\mathrm{H}_{2}$ : There is a negative relationship between the Board's effectiveness and Firm's Financial Performance.

\subsection{Board Size and Structure:}

$\mathrm{H}_{1}$ : There is a positive relationship between the Board's Size \& Structure and Firm's Financial Performance.

$\mathrm{H}_{2}$ : There is a negative relationship between the Board's Size \& Structure and Firm's Financial Performance.

\subsection{Board's Independence:}

$\mathrm{H}_{1}$ : There is a positive relationship between the Board's Independence and Firm's Financial Performance. 
$\mathrm{H}_{2}$ : There is a negative relationship between the Board's Independence and Firm's Financial Performance.

\subsection{CEO Duality:}

$\mathrm{H}_{1}$ : There is a positive relationship between the CEO Duality and Firm's Financial Performance.

$\mathrm{H}_{2}$ : There is a negative relationship between the CEO Duality and Firm's Financial Performance.

\subsection{Board's Education and Experience:}

$\mathrm{H}_{1}$ : There is a positive relationship between the Board's Education and Experience \& Firm's Financial Performance.

$\mathrm{H}_{2}$ : There is a negative relationship between the Board's Education \& Experience and Firm's Financial Performance.

\section{Delimitation of the Study:}

- The study was delimited 30 listed companies of Karachi Stock Exchange (KSE) of Pakistan and New York Stock Exchange (NYSE) of USA.

- Only the companies which have complete required data available was included in the sample.

- The study was limited between two countries i.e. Pakistan and USA only for Developing and Developed Country respectively.

\section{Literature Review:}

\subsection{Corporate Governance:}

The world has faced great failures of many giant firms in the past decade and major scandals were pointed out which results in these failures. On thorough investigations of these failures, this has been revealed that these scandals emerge due to lack of corporate governance practices. This shaken the world's economy and investors and shareholders started to go for precautionary measures which is implementing corporate governance in the firms. They were forced to acknowledge the fact that corporate governance is a best cure in this regard which reduces the risk of shareholders so it requires special attentions for implementing it into the companies (El Mehdi 2007). Hence this aspect has also motivated the researchers to conduct the research on this topic i.e. corporate governance in order to implement in that way so that it may increase the performance of the firm.

Shlidfer and Vishney (1997) describe the corporate governance as it assures the shareholders that they will get return on their investment. They emphasized as the corporate governance determines the agency aspect as how shareholders 
motivate the managers to give their return to them. Like they pay them extra bonuses and provide different facilities just to safeguard their investment and its return.

Evidence from the past studies have revealed that corporate governance improves the firm's financial performance either it is in developed world or under developed country. Study results of Demsetz (1983), Demsetz \& Lehn (1985), and Shleifer and Vishny (1989) shows that those firms where outside directors are present, they show abnormal return on the investment.

Hecht, Benson and Finegold (2007) conducted the study on the relationship between the corporate board and firm's financial performance and found out that the setting up corporate board rules leads to the better performance of the company. Sen (2001) conducted the same study with an objective to create a variable to measure the corporate governance and found that the board mechanism do impact on the performance. Some of the studies show that with weak corporate governance, they also do not perform well, Core, Guay and Rusticus (2004). ZA Shah (2009) conducted a comparative study of corporate governance on firm's financial performance between US (Developed Country) and Pakistan (Underdeveloped Country) and concluded a positive relationship between them.

In the various studies the corporate governance has been measured through different variables which are Ownership of the board, effectiveness of the board, Board size, independence of directors, and duality of CEO and Education along with experience of the board. In order to elaborate the importance of each variable, the literature in this respect is detailed as under:

\subsubsection{Board's Ownership}

This aspect is being under discussion for a long time. Several authors / researcher have given various reasons for differences in board ownership. Jensen and Murphy (1990) revealed that board's ownership improves the performance. Brickley et al. (1988) has concluded that the ownership of the board is an encouraging aspect for the board members. This brings their personal interest in the company's matters and they take better decisions which are helpful for other stake holders. There is a positive relationship between board's ownership and firm's financial performance Mehran (1995). Fama and Jensen (1983) declared this aspect as "two-edged knife" which have maximum and optimal benefit and enhancement in firm's financial performance.

\subsubsection{Effectiveness of the board:}

Corporate governance provides a way as how to deal with the agency cost and agency problems. In other words, the main objective of corporate governance is 
met by dealing with agency problems (Jensen and Meckling 1976). It considers that the objective of management and board are not similar rather it depends upon how much compensation the management gets from the board and from the company so that the interest of shareholders is met. This providing the compensation brings out the solution for any problem arising between the management and shareholders and in this way the shareholders gets the confidence on the management and also management safeguard the interest of shareholders. The presence of the board reduces the agency cost (Kee et al (2003) and Hutchinson \& Gul (2003).

\subsubsection{Board Size and Structure:}

As far as the corporate governance is concerned, the structure and size of the board is most important factor to be considered. The board size should not be very large that it costs huge financial burden which is higher than the agency cost nor the board should be too small that it may lead to the biased decisions or weak decisions. Non-executive directors takes the efforts and measures in order to ensure that the organization is running effectively and they monitor the performance of the management in order to retain the firm's reputation in the market, Fama \& Jensen (1983). Talking about the board size, two school of thought exists, one says that smaller board size contribute more and better in the best interest of the organization, Pfeffer (1972), Ctg and Coles (2008), whereas other school of thought is of the view that large board size provides the better results and it improves the performance of the organization. As it brings out better and more information from the board members and the decision making is more effective and well informed, Klein (1998), Dalton (1999).

\subsubsection{Independence of the Board:}

Board's independency is very important aspect in the corporate governance as the when the organization's board is independent they will take better and unbiased decisions as well as the firm will have less financial pressure. Those firms which have their board as an independent they tend to face less financial pressure, Elloumi and Gueyie (2001). Higher number of independent directors in the board in the companies can enhance the decision credibility and objectivity. When there is an independent system exists regarding the board of directors, there would be a transparency in financial statements and value, Chau and Gary (2010). Independency of the board also tends to have better supervision and protection of shareholders equity increases, Fame \& Jensen (1983).

Independent directors also supervise the hierarchy of the management in a better and unbiased way. If the number of independent directors is higher in 
the board then dependent board members then the performance of the company enhances, Yonca Ertimura, Fabrizio Ferrib (2010).

\subsubsection{Duality of CEO:}

Duality of CEO means that one person is having both responsibilities in the company i.e. CEO and Chairman of the Board. This lead to the highly biased decision and monopoly of a single person arises which tends to have lack of confidence of other board members and as well as the performance of the company also reduces. This creates an imbalance of the power within the firm and the influence of one person in all matters of the organization results in highly biased and ineffective decisions.

Keeping this aspect of duality, much organization has followed this point, that they made their CEO and Board's Chairman, separate and hence moved from duality to a non-duality structure of the organization, Chen, Li and Yi (2008). Duality of the board reduces the supervision and monitory process on the management of the organization, Fama and Jensen, (1983).

\subsubsection{Board's Education and Experience:}

The board is the back bone of the organization as it monitors the operations of the management and similarly protects the interest of the shareholders. They also evaluate the management and take decision which is helpful for the organization. It is, therefore, the education level of the board must be better so that they can inspect the current situations and take measures and decisions accordingly. The board must be fully equipped with the knowledge in order to cope up with all matters of the organization. There is utmost requirement of the board to contribution is made from each member and this contribution is then implemented in the enhanced performance of the organization, Nicholson \& Kiel, (2004). Suffient professional competency is better and essential of the directors for having better decisions, Forker (1992).

There is a conflict view on the board's experience and firm's financial performance as those members will have higher experience who are of old age so at that age the aggression increases and this results in risky decisions. Also high aged members are not updated with the latest innovations thus this tends to lack of better decisions for the organization, Child (1975). Although there remains a conflict over the board's experience but a sufficient board experience and updated member can take better decisions in the best interest of the organization, Wegge et al (2008).

\subsection{Performance of a Firm:}

By firm's financial performance, it is referred to as measure the efficiency and effectiveness of organization internal as well external actions / operations. In 
today's world, the performance of the organization is considered as the body of the organization because if the performance of a firm is well enough only than its growth would be enhanced. The performance of the firm can be seen from its financial statements which are reported by the company. Herly and Sisnuhadi (2011) stated that if the company is performing well it will support the management for quality disclosure of their operations. In order to get the growth in the organization, it needs to be measure as what the organization is performing currently which will bring out the gap needed to be filled to attain the objectives of the organization.

\subsubsection{Measuring Firm's Financial Performance:}

Basically the success of the firm is measured through its performance which is analysed through different tools and techniques. Many analyst uses different techniques for measuring the financial performance but most of the investors focused on the tool like Return on Equity and Return on Asset in order to ascertain the financial performance of the company, John H, S. Brown and L. Davison (2010).

\section{Theoretical Framework:}

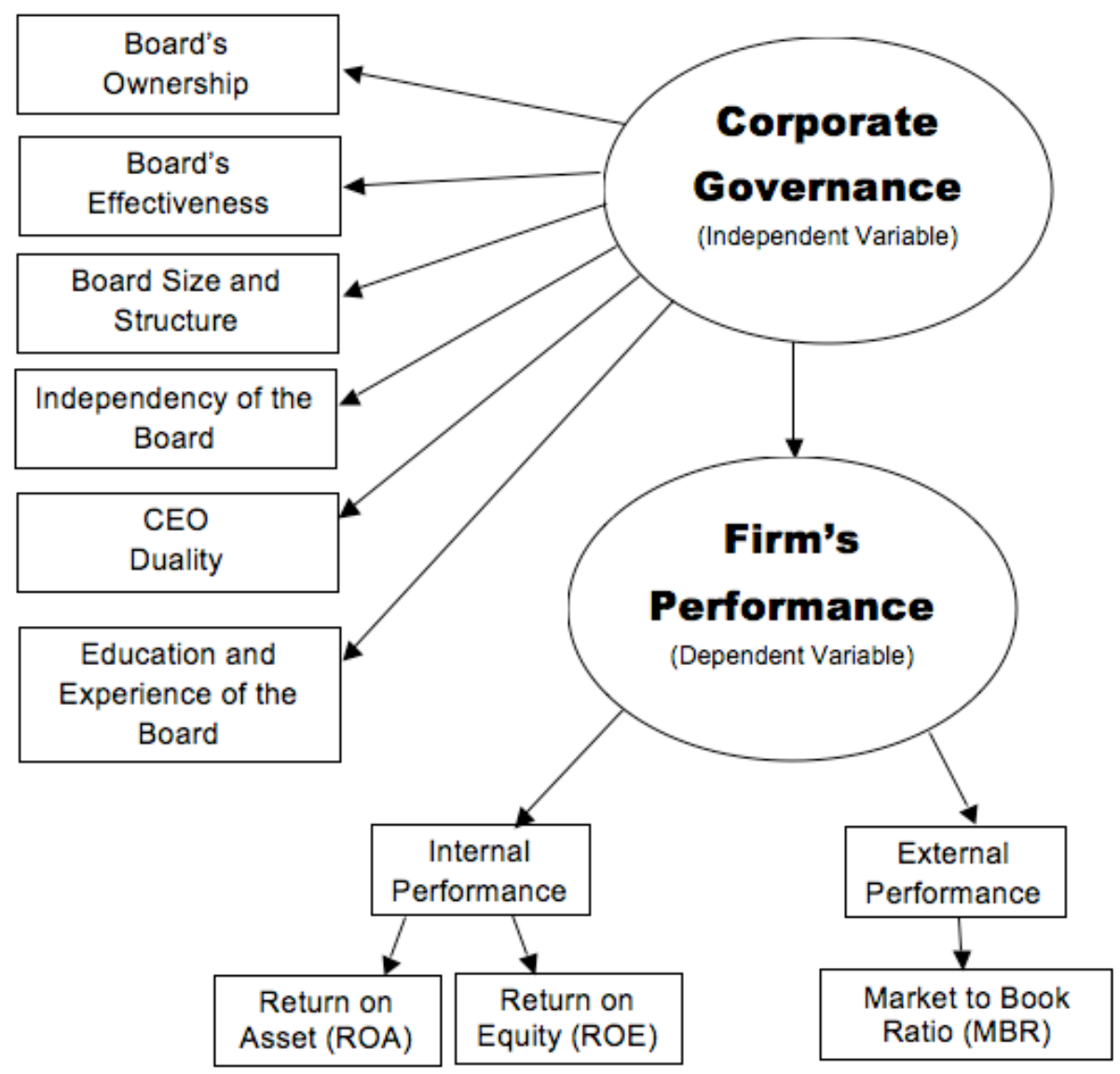




\section{Research Methodology:}

The objective of the study is to measure the effect of corporate governance on Firm's financial performance by making a comparison of Pakistan (Developing Country) and USA (Developed Country). Corporate Governance is measure through Board's Ownership, Effectiveness, Size and Structure, Its Independency, CEO Duality and Board's education and Experience whereas the firm's financial performance is measure by the Return on Asset and Return on Equity for measuring internal performance and Market to Book Ratio (MBR) for measuring external performance of the organization.

\subsection{Measuring Corporate Governance:}

Instrument used for measuring the corporate governance is the questionnaire (given at appendix A) containing closed ended questions asked from Directors, Executives, Managers and Junior Managers of selected organization to gather the primary data for measuring the hypothesis of variables of corporate governance.

\subsection{Measuring Firm's Financial Performance:}

The firm's financial performance is measured through two aspects i.e. Internal Performance and External Performance.

\subsubsection{Measuring Firm's Internal Financial Performance:}

For measuring the firm's internal financial performance, accounting tools were used i.e. Return on Asset and Return on Equity. ROA is the indicator as what profit the company is earning against its available resources i.e. Assets and ROE term indicates that how much the company is earning to the ratio of investment of shareholders. Both these indicators brings out the internal performance of the company and shows the earning aspect of the company.

ROA $=\hat{a}_{0}+\hat{a}_{1}$ Boardsize $+\hat{a}_{2}$ Board Structure $+\hat{a ̂}_{3}$ CEO Duality + â4Board Education + âsBoard Experience + â6Board Ownership + â7Board Effectiveness $+a_{i} i$

$\mathbf{R O E}=\beta_{0}+\beta_{1}$ Boardsize $+\beta_{2}$ Board Structure $+\beta_{3}$ CEO Duality $+\beta{ }_{4}$ Board Education $+$

$\beta{ }_{5}$ Board Experience $+\beta{ }_{6}$ Board Ownership $+\beta$ B Board Effectiveness $+\beta_{i}$

Where â 0 and $\beta 0$ are the constant and åi \& $\beta$ i referred to as infinite number of variables.

\subsubsection{Measuring Firm's External Financial Performance:}

Firm's external financial performance is measure by comparing its market value of share from its book value of the share. Book value of the share is determined by dividing total shareholder equity with total outstanding share. For analyzing Tobin's Q formula / technique of measuring Market to Book Value is used in 
which the book value is compared from its market value (the price at which the share is being traded). In order to ascertain the Market to Book Ratio, book value is divided by market value, gives market to book ratio of the company. This MBR identifies that either the share is overvalued or it is undervalued which shows its future direction or movement of the price.

\subsection{Population Size:}

The population of the study is categorized as under:

- $\quad$ All listed companies of Karachi Stock Exchange (KSE)

- $\quad$ All listed companies of New York Stock Exchange (NYSE)

\subsection{Sample Size:}

The selected sample from the population of the study on the basis of availability of corporate governance data:

- 30 listed companies of KSE

- $\quad 30$ Listed companies of NYSE (From the same sector as selected in KSE)

\subsection{Instrument:}

For collecting information regarding the Corporate Governance, Questionnaire was drafted (Appendix - A). This questionnaire contains closed ended questions and made simplified for better understanding of the respondents.

\subsection{Data Collection:}

Data from Pakistan obtained by physically floating of the questionnaire in listed companies of Pakistan and for USA, the questionnaire was floated online (due to non-reachable physically). For getting information / data related to the financial firm's performance, financial reports of 30 listed companies of Karachi Stock Exchange and 30 selected companies of New York Stock Exchange were downloaded for the period 2010 to 2015 from their official website. Each financial reports was studied for gathering the information like firm's total assets, equity, number of outstanding shares and book value of the share and compiled in the excel sheet for further analysis. Similarly for obtaining information about the market value of share, it has been obtained from Karachi Stock Exchange and New York Stock Exchange official website of last closing price as on period Dec 2010 to Dec 2015.

\section{Data Analysis and Results:}

Questionnaire were floated to 50 respondents both for Pakistan and USA against which 45 respondents in respect of Pakistan and 33 respondents gave their comments on the online questionnaire in respect of USA. These responses were then analyzed through excel sheet which showed the following results. 


\subsection{Analysis of Data in respect of Pakistan:}

Pakistan being a developing country investigated in the study and found the data which is analyzed here under:

In the response $33 \%$ companies were relating to manufacturing area and the rest were from service industry which mostly includes the banking sector. It has been analyzed there is a direct relationship of Board's ownership with the corporate governance. Similarly direct relationship also exists for effectiveness of the board. This means that those firms who have strong ownership of the board they tend to have better power on the management. In respect of CEO Duality, mixed response has been seen the main reason for this is as the same person holds two position i.e. he is CEO and Chairman of the board at the same time, the person tends to take better decision because of complete interest and have the trust of the shareholders.

Other than the above, corporate governance codes are maintained only in listed companies but only in those who are not family owned business or those in which a family has the management control. Those companies which are owned by family, they tends to follow their own set procedures when corporate governance codes are conflicting with their SOPs.

\subsection{Analysis in respect of USA:}

Pakistan being a developed country investigated in the study and found the data which is analyzed here under:

$21 \%$ companies were from manufacturing, 53\% companies from service industry and $26 \%$ were government owned firms from which respondents responded to the online questionnaire. Being a developed nation and better understanding and implementation of corporate governance codes / rules, this listed organization follow strict corporate governance codes. The entire variable has positive relationship with the firm's performance but Board Size has negative correlation. The reason for this is that if the board size is bigger than it will increase the conflict of interest and delay in the decision process. In order to overcome this aspect, then better qualified and experienced board which contains only the expert relating to all fields of work can take better and quick decisions as compared to the bigger board. Hence due to better alignment of firm's SOPs with Corporate Governance codes of USA, the performance of the firm's is better and sustainable.

\section{Conclusion:}

The study compares / explores the relationship of corporate governance with firm's performance between the two countries i.e. Pakistan (a developing country) and USA (a developed country). 
From the study it has been found that there are some similarities between the two countries which were used for investigation. However, corporate governance codes are being followed in both countries but it is better in the developed countries. In Pakistan, there are mostly family owned business in which they have their own set procedures. When these are in conflict with already drawn CG codes by SECP, these companies follows their own set procedure whereas in USA strict CG codes are being followed. The variables like Board ownership, Board Education \& Experience, effectiveness and CEO Duality has positive relationship with the firm's performance but Board Size has negative correlation. The reason for this is that if the board size is bigger than it will increase the conflict of interest and delay in the decision process. In order to overcome this aspect, then better qualified and experienced board which contains only the expert relating to all fields of work can take better and quick decisions as compared to the bigger board.

The study also found that there is no relationship between independency of director with firm's performance. Hence due to better alignment of firm's SOPs with Corporate Governance codes of USA, the performance of the firm's is better and sustainable. 


\section{References}

Adams, R., B. and Ferreira, D. (2007), "A theory of friendly boards". Journal of Finance, 62(1), 217-250.

Becker, B. et al (2011), "Estimating the effects of large shareholders using a geographic instrument". Journal of Financial and Quantitative Analysis, 46(4), 907-942.

Bhabra, G., S. et al (2003), "Corporate Governance in Singapore: The Impact of Directors' Equity Ownership". Advances in Financial Economics, 8, 29-46.

Brickley, J., A., Lease, R., C. And Smith, Jr., C. (1988), “Ownership structure and voting on antitakeover amendments". Journal of Financial Economics, 20, 267-291.

Vietnam Ministry of Finance (2012), “Circular No. 121/2012/TT-BTC dated on July 26, 2012 issuing the regulations on corporate governance which is applied to public companies".

Burkart, M., Gromb, D. and Panunzi, F. (1997), "Large shareholders, monitoring, and the value of the firm". The Quarterly Journal of Economics, 112(3), 693-728.

Carlson, R., Karlsson, K. (1970), "Age, cohorts, and the generation of generations". American Sociological Review, 35(4), 710-718.

Chen, C., W., Lin, J., B. And Yi, B. (2008), “CEO Duality and Firm Performance: An Endogenous Issue". Corporate Ownership and Control, 6(1), 58-65.

Child, J. (1975), “Managerial and Organizational Factors Associated with Company Performance - Part II. A Contingency Analysis". Journal of Management Studies, 12, 12-27.

Chung, K., H. and Pruitt, S., W. (1996), "Executive ownership, corporate value, and executive compensation: A unifying framework". Journal of Banking and Finance, 20(7), 1135-1159.

Coles, J., L., Daniel, N., D. and Naveen, L. (2008), “Boards: Does one size fit all?” Journal of Financial Economics, 87(2), 329-356.

Dahya, J., Garcia, L., G. And van Bommel, J. (2009), “One Man Two Hats: What's All the Commotion!" The Financial Review, 44(2), 179-212.

Dalton, D., R. et al (1999), "Number of Directors and Financial Performance: A Meta-Analysis". The Academy of Management Journal, 42(6), 674-686.

Daily, C., M., Dalton, D., R. and Cannella, A., A. (2003), "Corporate Governance: Decades of Dialogue and Data". The Academy of Management Review, 28(3), 371-382.

Denis, D., K. And McConnell, J. (2003), “International Corporate Governance”. 
Journal of Finance and Quantitative Analysis, 38(1), 1-36.

Dutta, P. and Bose, S. (2006), "Gender Diversity in the Boardroom and Financial Performance of Commercial Banks: Evidence from Bangladesh". The Cost and Management, 34(6), 70-74.

Elloumi, F. and Gueyié, J., P. (2001), "Financial distress and corporate governance: an empirical analysis". Corporate Governance, 1(1), 15-23.

Fama, E., F. (1980), "Agency problems and the theory of the firm". Journal of Political Economy, 88(2), 288-307.

Fama, E., F. and Jensen, M. C. (1983), "Separation of ownership and control". Journal of Law and Economics, 15(2), 301-325.

Fairchild, L. and Li, J. (2005), "Director Quality and Firm Performance". The Financial Review, 40(2), 257-279.

Gedajlovic, E., R and Shapiro, D., M. (1998), “Management and Ownership Effects: Evidence from Five Countries". Strategic Management Journal, 19(6), 533-553.

Heidrick \& Struggles (2009), “Corporate Governance Report 2009 - Boards in turbulent times". Heidrick and Struggles International, Inc.

Hewa-Wellalage, N. and Locke, S. (2011), “Does CEO Duality is really Matter? Evidence from an Emerging Market". Corporate Ownership and Control, 8(4), 112-122.

Jensen, M., C. (1993), "The Modern Industrial Revolution, Exit, and The Failure of Internal Control Systems". The Journal of Finance, 48(3), 831-880.

Jensen, M., C. and Meckling, W., H. (1976), "Theory of the Firm Managerial Behavior, Agency Costs and Ownership Structure". Journal of Financial Economics. 3(4), 305-360.

Jensen, M., C. and Murphy, K., J. (1990), “Performance Pay and TopManagement Incentives". Journal of Political Economy, 98(2), 225-264.

Klein, A. (1998), "Firm Performance and Board Committee Structure". Journal of Law and Economics, 41(1), 275-303.

Lipton, M. and Lorsch, J., W. (1992), “A modest proposal for improved corporate governance". Business Lawyer, 48(1), 59-77.

Mehran, H. (1995), "Executive Compensation Structure, Ownership and Firm Performance". Journal of Financial Economics, 38(2), 163-184.

Myers, S., C. (2000), “Outside Equity”. The Journal of Finance, 55(3), 1005-1037.

Nicholson, G., J. and Kiel, G., C. (2004), "Breakthrough board performance: how to harness your board's intellectual capital". Corporate Governance: The International Journal of Business in Society, 4(1), 5-23.

Pfeffer, J. (1972), "Size and Composition of Corporate Boards of Directors: The 
Organization and its Environment". Administrative Science Quarterly, 17(2), 218-228.

Shleifer, A. and Vishny, R., W. (1997), "A Survey of Corporate Governance". The Journal of Finance, 52(2), 737-783.

Smith, N., Smith, V. And Verner, M. (2006), “Do Women in Top Management Affect Firm Performance? A Panel Study of 2500 Danish Firms". International Journal of Productivity and Performance Management, 55(7), 569-593.

Truong, Q. and Dang, C. (1998), "Effective leadership in joint ventures in Vietnam: a cross- cultural perspective". Journal of Organizational Change Management, 11(4), 357-372.

Wegge, J. et al (2008), “Age and Gender Diversity as Determinants of Performance and Health in a Public Organization: The Role of Task Complexity and Group Size". Journal of Applied Psychology, 93(6), 13011313.

Wooldridge, J., M., (2002), "Introductory Econometrics: A Modern Approach". 2nd Ed., South-Western College.

Yermack, D. (1996), "Higher Market Valuation of Companies with a Small Board of Directors". Journal of Financial Economics, 40(2), 185-211.

Z.A Shah, (2009), "Corporate governance and financial performance. A comparative study of developing and developed markets." Journal of Corporate Governance, 30(1), 142-195. 